\title{
JOB LOSS DOES NOT CAUSE ILL HEALTH
}

\author{
Martin Salm
}

163-2008

๑ $\boldsymbol{m e a - M a n n h e i m ~ R e s e a r c h ~ I n s t i t u t e ~ f o r ~ t h e ~ E c o n o m i c s ~ o f ~ A g i n g ~}$

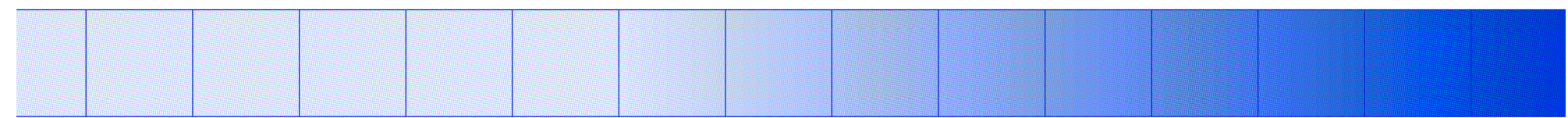

L13, 17_D-68131 Mannheim_Phone +49 621 181-2773/1862_Fax +49 621 181-1863_www.mea.uni-mannheim.de 


\title{
Job loss does not cause ill health
}

\author{
Martin Salm, MEA, University of Mannheim
}

August 2008

\begin{abstract}
:
I use longitudinal data from the Health and Retirement Study to estimate the effect of job loss on health for near elderly employees. Job loss is a major cause of economic insecurity for working age individuals, and can cause reduction in income, and loss of health insurance. To control for possible reverse causality, this study focuses on people who were laid off for an exogenous reason - the closure of their previous employers' business. I find that the unemployed are in worse health than employees, and that health reasons are a common cause of job termination. In contrast, I find no causal effect of exogenous job loss on various measures of health. This suggests that the inferior health of the unemployed compared to the employed could be explained by reverse causality. I also use instrumental variable regression to estimate the effect of loss of health insurance, loss of income, and re-employment on health, and again find no statistically significant effects.
\end{abstract}

Address: Martin Salm, L13, 17, 68131 Mannheim, Germany

E-mail: salm@mea.uni-mannheim.de

I thank Padmaja Ayyagari, Han Hong, Ahmed Khwaja, Jan Osterman, Frank Sloan, Alessandro Tarozzi, Curtis Taylor, and seminar participants at Duke University and the University of Mannheim for valuable suggestions. 


\section{Introduction}

Unemployment is a major cause of economic insecurity for working-age Americans. Loss of employment is often linked with a loss of income and employer provided health insurance, as well as the loss of valued relationships, status, and identity. There are well-documented negative correlations between health and lower income (see surveys in Goldman (2001) and Smith (1999)), health and lack of health insurance (see surveys by Haudley (2003) and Levy and Meltzer (2001)), and health and unemployment (see discussion in Catalano et al. (2000)). However, for all three of these correlations the directions of causality have proved difficult to establish. In this study I look at business closures as a natural experiment that can be used to test for a causal relationship from job loss on health, and job loss induced loss of income and health insurance on health.

I use data from the Health and Retirement Study (HRS), a nationally representative survey of near elderly Americans. For the purpose of examining the causal effects of job loss on health the HRS offers several advantages: 1) The HRS includes detailed information on the causes of the termination of employment contracts. In this paper, I only consider individuals who lost their job because of business closure, which is arguably exogenous to employees' health. This definition of job loss sets this study apart from most previous studies that don't control for the cause of unemployment. 2) The HRS is a panel data set. 3) The HRS includes detailed information on demographics, health, income, education, health behaviors, community characteristics, job characteristics, and the ex-ante subjective probability of involuntary job loss. This information can be used to control for differences between the characteristics of people who are affected by job loss and those who are not affected by job loss.

This study uses a differences-in-differences estimation approach. It follows a cohort of initially employed individuals and compares the subsequent changes in health of those who lose their job due to business closure with a control group of those who don't lose their jobs. I also use instrumental variable regressions to estimate the effect of loss of health insurance, loss of income, and re-employment on health.

I test the robustness of my results by performing estimations for various measures of physical and mental health, various sets of covariates, and by including other reasons 
of job termination that might not be exogenous to health, such as being laid off for any reason, quitting a job, or explicitly leaving for health reasons. I examine how the health effects of job loss vary by gender, race, marital status, income, and education level, as well as previous working conditions. Further, I test if there is a difference in the effect of job loss for people who anticipated a lay-off compared to those who are dismissed unexpectedly, and finally, I examine the effect of a spousal job loss on health.

In contrast to most previous studies that use cross-sectional datasets or broader definitions of job loss, I find no effect of exogenous job loss on health for any of my specifications. I find that causes of unemployment that are endogenous to health, such as leaving a job for bad health, are common and associated with a substantial deterioration in health. My results suggest that the negative correlation between health and unemployment could be explained by reverse causality. I also find no statistically significant effects of loss of health insurance, loss of income, and re-employment on health.

The paper proceeds as follows: Section 2 discusses the previous literature with a focus on the problem of causal inference. Section 3 outlines the identification strategy, and discusses the estimation methods. Section 4 describes the data. Section 5 presents and discusses the estimation results. Section 6 concludes the paper.

\section{Previous literature}

This study is part of a literature that examines the effects of job loss and unemployment on health. Some previous studies in the economics literature examine this relationship (Bjorklund 1985, Mayer et al. 1991, Gerdtham and Johannesson 2003), and there is also a large literature on this topic in the epidemiology, psychology, public policy, and sociology literatures. Most of these studies compare various measures of physical and mental health between the employed and unemployed, often with a focus on how the effects of unemployment differ for specific racial and ethnic groups (Rodriguez et al. 1999, Catalano et al. 2000), gender, family role, and social class (Artazcoz et al. 2004, Price, Choi and Vinokur 2002, Dew et al. 1992), unemployment benefit type (Rodriguez 2001), and community characteristics (Turner 1995). These studies mostly 
find that the unemployed are in worse physical and mental health than the employed. However, such an association does not necessarily imply a causal relationship from unemployment to ill health. It could also be explained if people in ill health are more likely to become or remain unemployed, either because of their ill health or because of third factors that are correlated with both ill health and unemployment. There is some empirical evidence that people in ill health are more likely to lose their jobs and become unemployed (Arrow 1996), and that unemployment spells are longer for people with health problems (Stewart 2001). In order to study the causal relationship from unemployment to health it is necessary to control for the cause of entry into unemployment, and also to account for the fact that unemployment spells might be longer for people in ill health.

One strategy to address reverse causality is to control for the current health of employed and unemployed individuals and compare their future health or mortality. However, this strategy yields unbiased estimates only if there is no unobserved heterogeneity between the employed and unemployed. For example, Gerdtham and Johannesson (2003), who follow this approach, do not include information on health behaviors, and differences in health behaviors such as smoking could lead to biased estimates of the mortality risk of the unemployed compared to the employed, even after controlling for differences in current health.

Another strategy is to control for lagged health. For example, Rodriguez et al. (1999) include variables for depression and general health five years prior to the second interview. However, if deterioration in health after the previous interview, but before the loss of employment is correlated with current unemployment, then comparing the health of unemployed and employed individuals will lead to a biased estimate of the health effects of unemployment, even after controlling for previous health.

This objection can be addressed by accounting for the cause of the loss of employment. For example, Catalano et al. (2000) look only at people who had been fired or laid off. Their sample excludes people who either quit their jobs on their own, or reported clinically significant substance abuse, because this illness is associated with both depression and job loss. However, the estimation results could still be biased, if lay-offs 
are related to health, if for example some people are laid off because of sickness related work absences. This bias can be avoided by studying the health effects of job loss for a cause that is exogenous to employees' health. Such a reason could for example be mass lay-offs. To my knowledge, only one previous study looks at the health of individuals who lost their jobs because of mass-layoffs. Dew et al. (1992) compare the mental health of a group of 141 women before and after layoffs at a plant in semi-rural Pennsylvania. During the twelve months following the first interviews, 73 of these women had been laid-off. They find a significant effect of lay-offs on mental health. However, it is not clear whether their findings for a small group of blue-collar female workers can be generalized to the overall population. My approach to solve the problem of selection into unemployment by health status is to include only individuals who lost their job, because their previous employer's business closed. This definition of job loss sets this study apart from most previous studies.

Another cause of potentially biased estimation results is that not only the reason of entry into unemployment, but also the length of stay in unemployment could be related to health. Catalano et al. (2000) take this into account by looking only at people who were laid off from work seven to twelve months before the interview. However, their results could still be biased if healthier job losers find new employment faster, and therefore are less likely to be unemployed seven to twelve months after being laid-off. Bjorklund's (1985) definition of unemployment includes people who are either currently unemployed or were unemployed at any time during the preceding year. My study includes people who have been laid-off because of business closure at any point of time within a two-year period, independent of their unemployment status at the time of the second interview. This approach allows the consistent estimation of the causal effect of job loss on health.

Beyond looking at the average effect of job loss on health, this study also examines the effects of job loss induced loss of income and health insurance, and the effects of employment status on health. There exists a large literature on the interdependent relationships between health and socio-economic status (SES), which is surveyed in Goldman (2001), and Smith (1999) (see also references in Adams et al. (2003)). A key problem in this literature is to control for the direction of causality. Ettner 
(1996) and Meer, Miller, and Rosen (2003) estimate the effect of income and wealth, respectively, on health using instrumental variable regressions. Ettner uses years of work experience, state unemployment rates and parental and spousal education as instruments for income, while Meer et al. use inheritances as instruments for wealth. However, each of these instruments is subject to weaknesses: Total work years could depend on previous health, state unemployment rates might affect health in other ways than just income, spousal matching could depend on health, and parental wealth and education might affect health not only through inheritances and higher income, but they might be also linked through other factors such as childhood health investments. Lindahl (2005) uses lottery prizes as an exogenous cause of variation in income. However, even lottery gains could be endogenous to health, if wealthier or healthier people buy more lottery tickets. This study contributes to the literature on health and SES by examining the health effects of job loss, an arguably exogenous event that causes a substantial reduction of income and consumption (Chan and Stevens 2002, Stephens 2004). This is true not only for the unemployed, but also for many laid-off workers who start a new job. Chan and Stevens (2002) find that job loss reduces earning for near elderly employees one year after job loss by between $20 \%$ and $33 \%$. However, there is a substantial variation in the size of the wage cut. Laid-off individuals with very short job tenure lose little, while those with the longest job tenure lose most (Stevens 1997).

As for the literature on health and income, reverse causality is also a major concern in the literature on health and health insurance, which is surveyed by Haudley (2003), and Meltzer and Levy (2004). Several previous studies use natural experiments such as expansions of public insurance programs (Currie and Gruber 1996, Hanratty 1996, Lichtenberg 2001), or differences in state-level Medicaid policy (Goldman et al. 2001) to estimate the causal effect of health insurance on health. These studies typically focus on groups such as small infants (Currie and Gruber 1996, Hanratty 1996), the elderly (Lichtenberg 2001) or HIV positive individuals (Goldmann et al. 2001). There is less evidence about the effects of health insurance for the general working-age population. Employment based health insurance is the most common source of health insurance in the U.S. Although health insurance is usually also available in the individual health insurance market, it tends to be more expensive. Job loss due to business closure is 
arguably a natural experiment that increases the price of health insurance, at least for those laid-off employees who were covered by employment based health insurance. Employees who are covered by for example their spouses' health insurance, or by government health insurance programs, or who never had health insurance in the first place, are not affected.

This study also examines the effect of re-employment on health. Job loss causes spells of unemployment and makes withdrawal from the labor force more likely (Ruhm 1991, Chan and Stevens 2001). This could be good for health if people, who are not working, use their additional spare time to exercise, cook healthy meals, or engage in other health improving activities. Ruhm $(2000,2005)$ finds that mortality rates and harmful health behaviors decrease in recessions, which he attributes to less work hours.

\section{Identification strategy}

The main parameter of interest in this study is the average effect of job loss on the health of those who lost their job. A formal definition of this effect, similar to Heckman et al. (1997) is:

$$
\alpha=E(Y(i, 1)-Y(i, 0) \mid D(i, 1)=1)-E(Y(i, 1)-Y(i, 0) \mid D(i, 1)=0)
$$

where $Y(i, t)$ is the health of individual $i$ at time $t$. The population is observed in a pre-treatment period $\mathrm{t}=0$, and a post-treatment period $t=1$. I denote $D(i, 1)=1$ if individual $i$ has been affected by job loss between periods $t=0$ and $t=1$, and $D(i, 1)=0$ otherwise.

The parameter $\alpha$ represents the difference between the health change of people affected by job loss and their hypothetical (counterfactual) health change if they had not been affected by job loss. Unfortunately, the counterfactual is never observed. Therefore, I need to assume that without job loss the health of people who in fact have been laid off would have evolved in the same way as it did for people with the same observed characteristics who have not been laid off. If $i^{\prime}$ is an individual in the control group (not laid off) with the same observed characteristics as $i$, an individual in the treatment group (laid off), then this assumption can be stated as: 


$$
E(Y(i, 1)-Y(i, 0) \mid X(i), D(i, 1)=0)=E\left(Y\left(i^{\prime}, 1\right)-Y\left(i^{\prime}, 0\right) \mid X\left(i^{\prime}\right), D\left(i^{\prime}, 1\right)=0\right)
$$

where $X(i)$ is a vector of observed characteristics predetermined at $t=0$. It is necessary to control for a sufficiently detailed set of relevant characteristics $X(i)$, because on average people affected by job loss do not have the same characteristics as people who are not laid off. Not controlling for differences between these groups would lead to biased estimation results. If for example the average laid-off employee is poorer or less educated than the average employee who is not laid-off, one might expect their health to evolve unfavorably compared to the health of the control group even in the absence of job loss. Observed characteristics in this study include information on demographics (age, gender, race), social situation (marital status, education, income and wealth), health behaviors (smoking, obesity, and health insurance), community characteristics (county unemployment rate, and county median household income). I also control for the ex-ante subjective probability of involuntary lay-off. Stephens (2004) finds that the subjective probability of involuntary lay-off includes information about the likelihood of subsequent job loss even after controlling for other characteristics, and that it is a good predictor of subsequent actual job loss. Including the subjective probability of involuntary lay-off controls for unobserved heterogeneity between people affected by job loss and others, which other observed characteristics could not detect. The average treatment effect can be estimated by the following linear differences-in- differences regression equation:

$$
Y(i, 1)-Y(i, 0)=\delta+X(i)^{\prime} \pi+\alpha D(i, 1)+\varepsilon(i)
$$

where the dependent variable is the change in health between period 0 (before the treatment) and period 1 (after the treatment), and $X(i)$ are assumed to be exogenous to the random error term $\varepsilon(i)$. The equation above can be estimated by standard regression methods such as least squares or ordered probit. I estimate the effects of job loss on several measures of health, and for alternative causes of job termination. These variables are described in section 4 .

So far, I discussed how to estimate the average effect of job loss on health. In the following, I will discuss how to estimate heterogeneous effects. Heterogeneity in the effects of job loss on health can be studied in a difference-in-differences estimation framework by specifying the treatment effect in the regression equation (2) as a function 
of variables $V(i)$ (i.e. by including interactions between $V(i)$ and $D(i, t)$ in equation (2)) (see Meyer 1995). The regression equation is now:

$$
Y(i, 1)-Y(i, 0)=\delta+X(i)^{\prime} \pi+\alpha D(i, 1)+D(i, 1) V(i)^{\prime} \beta+\varepsilon(i)
$$

Where $V(i)$ is a vector of variables with individual characteristics that determine how the effects of job loss on health vary among laid-off workers. Specifically, I examine how the effects of job loss on health vary by gender and marital status (for married women, married men, not-married women and not-married men), by race (for black vs. non-black people), by education (for people with or without a high-school or a college degree), and previous working conditions (whether the previous job involved lots of physical effort, stress, or was lowly paid), as well as to what degree the job loss was unexpected. Another specification examines in a sample of married people the effect of job loss on the health of a spouse. If these variables are exogenous to the error term, which I assume they are, equation (3) can be estimated by standard regression methods such as ordered probit or least squares.

By contrast, three of the factors examined in this study, namely the percentage change in household income, loss of health insurance, and whether laid-off employees work again after job loss, are likely to be endogenous to the change in health of laid-off employees. Deterioration in health can lower income both by reducing wages and by reducing labor supply. Declining health can also affect health insurance coverage, either by increasing the cost and difficulty of access to private insurance, or by making it more likely to qualify for public health insurance programs. Worsening health is also likely to decrease labor supply. If the treatment variable $D(i, 1)$ is interacted with endogenous variables $V(i)$ the effects of job loss on health can be estimated by 2SLS, provided that valid instrumental variables are available. Then, equation (3) represents the second stage of a 2SLS regression. In the following paragraphs, I present my instrumental variables and argue that these variables are likely to be valid instruments that is, they are correlated with the endogenous variable as well as uncorrelated with the error in the structural equation to be estimated. 
The instrumental variables I use are: years of job tenure at the lost job, source of health insurance -if any- and whether spouse was covered by own employment based health insurance, and the ratio of wage income as a share of total household income.

Laid-off employees with longer job tenure are likely to lose a larger share of their income (Stevens 1997), because they lose more company specific human capital, and also the component of their earnings that was based on seniority in the same firm. The risk of losing health insurance for laid-off employees depends on their previous source of coverage. If they were covered by employment based health insurance, they are more likely to lose health insurance than if they were covered by a government insurance program, or by the spouses employer of their spouse (see Table 6). For laid-off employees whose spouse was covered by employment based health insurance, coverage by the spouses' employer might be a readily available alternative source of health insurance. Furthermore, laid-off employees, whose wage earnings were a smaller share of total household income before job loss, that is who have access to more non-labor income as a share of total household income, are less likely to be employed again after job loss. The literature on labor supply finds that labor supply decreases with higher non-labor income (Blundell and MaCurdy 1999). The relevance of the instruments can be empirically tested by an F-test for all excluded instruments, and by the partial R-squared, which indicates how much the instruments contribute to the goodness of fit of the firststage regression.

I argue that all of these instruments are exogenous to the subsequent changes of health. They cannot be directly affected by changes in health after job loss, since they refer to the period before the job loss. They are also unlikely to be correlated with the error terms. Since the baseline regression already includes a variable for health insurance status, the source of health insurance coverage should not matter for subsequent changes in health. Also, whether a spouse is covered by his or her own employer provided health insurance, should not be correlated with the error term after controlling for own health insurance status, marital status, education, age, total household income and wealth. This also applies to job tenure, and wage income as a share of total household income. Because the number of instruments is larger than the number of endogenous variables, 
and as a mean to dispel residual doubts about the exogeneity of the instruments, I test the over-identifying restrictions using Hansen's J-statistics (Baum, Schaffer, Stillman 2003).

\section{Data and descriptive statistics}

I use data from waves two to six of the Health and Retirement Study (HRS) which cover the time period from 1994 to 2002 (www.hrsonline.isr.umich.edu). The HRS includes a sample of initially 7600 households (12654 individuals), with at least one household member born from 1931 to 1941, and their spouses, who could be any age. The survey was subsequently repeated every two years. In 1998 a new sample of 'war babies', who were born between 1942 and 1947, was added to the survey, and the data also include new spouses of previous wave respondents. For each individual, I use information from the first two waves that an individual respondent was in the sample. My sample includes persons who were age 65 or below the second time they were interviewed, and it includes only persons who were employed at the time of their first interview, since only the employed are at risk of being laid off. This leaves a sample of 8003 persons. Of these, 1878 were not asked about their subjective probability of involuntary job loss, and geographical information is missing for 101 observations. The final sample for the baseline regression (table 3, column 4) consists of 5985 people.

All respondents who did not work for their previous-wave employers were asked why they had left that employer. 148 persons (2.4\% of the total sample) answered that the business has closed. 277 persons stated that they were laid off, 219 quit, and 188 left for health reasons.

The dependent variable is a measure of health change between waves, which is captured by various subjective and self-reported objective measures of health. One variable that measures the change of health is the answer to the question how selfassessed health has changed since the last interview two years ago. Possible answers include 'much better', 'somewhat better', 'about the same', 'somewhat worse', and 'much worse'. The answer 'much better' is coded as 1 and 'much worse' is coded as 5. Another measure of health change is the change in limitations in activities of daily living (ADL's) since the previous interview. Activities of daily living include the ability to walk 
across a room, dress, eat, bath, use a toilet, and get in and out of bed without help. Another measure of health change is the change in longevity expectations. Longevity expectations are measured as the subjective probability to live to age 75 or longer, and changes in answers between waves are measured relative to life-table averages. I also use two measures of change in mental health, the first of which is the change in CESD scores (Center for Epidemiologic Studies Depression Scale). Respondents are asked whether they agree or disagree with eight statements about their emotions during the past week, such as whether they felt depressed much of the time. The CESD score is based on the answers to these questions and ranges from 0 (good mental heath) to 8 (bad mental health). The second measure of mental health change is a binary variable that indicates whether there was a first incidence of a doctor diagnosed psychological condition between interview waves. Further, in one regression I use a measure of same-period selfreported overall health as dependent variable. Possible answers range from 'excellent' (codes as 1) to 'very good' (2), 'good' (3), 'fair' (4), and 'poor' (5).

One concern with respect to the dependent variables is that the differences between categories might not be equal. For example the difference between 'much better' health and 'somewhat better' health might not be the same as the difference between 'somewhat better' health and 'about the same health'. One solution to this potential problem is to use ordered probit estimation, which allows for different distances between categories.

Another question is whether self-reported health measures provide meaningful indicators of health status. Idler and Benyamini (1997) documented in a review of 27 studies that self-reported health measures are strongly correlated with mortality. Another concern about self-reported health measures that has received a lot of attention in the literature is that self-reports of health might be biased depending on labor force status, if people out of work are more likely to report ill health in order to justify economic inactivity. Several previous studies found evidence for such a justification bias, while others found no evidence (see review by Currie and Madrian 1999, and discussion in McGarry 2004). This study uses several measures of health change. Some of those, such as subjective longevity expectations and doctor diagnosed psychological conditions, are not likely to be affected by justification bias. For other measures such as self-reported 
health change, it is possible that the estimates of the negative effect of job loss on health change are upward biased.

Explanatory variables include respondents' age, and binary variables for respondents who are female, black, married, have a high school degree, and for respondents who have a college degree. Further explanatory variables are total household net wealth, and the logarithm of the total household income. Income and wealth are adjusted for consumer price inflation (CPI) and represent real 1982-1984 prices. Also included are binary variables about health behaviors, whether the respondent is currently smoking, is obese, which is defined as a body mass index (BMI) in excess of 30 , or is covered by health insurance, which could be provided through a present or former employer, spouses' employer, government program, or individual health insurance. Community characteristics are represented by the county median household income and the county unemployment rate, both in the year of the interview. The county level unemployment rates are from the Local Area Unemployment Statistics Files', published by the Bureau of Labor Statistics. The county level median household income variable is from the Bureau of Census' Small Area Income Poverty Estimates (SAIPE) for 1995, 1997, and 1998, and from the Census Population and Housing Demographic Profile for 2000. The subjective probability of job loss is based on the following question: 'Sometimes people are permanently laid off from jobs that they want to keep. On the scale from 0 to 100 where 0 equals absolutely no chance and 100 equals absolutely certain, what are the chances that you will lose your job during the next year?'

Table 1 shows sample statistics for both the overall population and those affected by job loss. Table 1 is based on the sample included in the baseline regression (Table 3, column 4). Compared to the overall population people who are affected by job loss due to business closing tend to live in counties with a somewhat higher average unemployment rate $(6.2 \%$ versus $5.7 \%)$, and lower median household income. They are more likely to be female, married, and have a high-school degree, but much less likely to have a college degree. On average, people, who will lose their job, live in households with somewhat lower incomes, and substantially lower wealth. They are more likely to smoke and be obese. They state that their jobs are less stressful and involve less physical effort. They are less likely to be employed in managerial or professional positions, and they are more 
likely to receive low pay, which is defined as an hourly wage below $\$ 4.72$ in 1982-1984 prices. Job tenure for people who will lose their job is 8.7 years. This is less than the average of 13.1 years for the overall population. To some degree, people anticipate being laid off. For job losers, the average subjective probability of being laid off was $32.5 \%$ compared with $14.9 \%$ for the total population.

People who lose their job suffer a substantial drop in household income, on average $-15.8 \%$ between waves, compared with an average gain of $5.1 \%$ for the overall population. For people who don't work, the average drop in household income is $-21.0 \%$, while for people who work for pay in the interview after the job loss, the average reduction in household income is $-11,8 \%$.

People who will lose their job are less likely to have health insurance. In this group $89.2 \%$ have insurance, compared with $92.5 \%$ of the overall population. However, after job loss the disparity widens, with only $77.7 \%$ of job losers being insured compared with $92.7 \%$ for the population. This indicates that job loss is often associated with the loss of health insurance. Of those who work in the interview after the job loss $80.9 \%$ have health insurance, compared with $73.4 \%$ of those who don't work. The sharpest drop is in employment based health insurance, which falls from $53.3 \%$ of the sample in the first interview to $35.8 \%$ in the second interview. This is not offset by a small increase in the share covered by government health insurance from $6.7 \%$ in the first interview to $9.4 \%$ in the second. There is little change in individual and spousal health insurance.

Job loss is also associated with a strong decrease in employment. All respondents are employed in the first interview. In the overall population $82.9 \%$ still work for pay in the second interview, while of those affected by job loss only $56.7 \%$ work.

\section{Results}

\section{A. Cross-section estimation of the relationship between unemployment and health}

The regression results in Table 2 show the association between being unemployed and self-reported overall health. Unemployment status and self- reported overall health are both measured at the time of the first interview in the sample. The sample differs 
from the samples used in the following regressions by including not only respondents who work for pay at the time of the first interview, but also those who are unemployed. The regression presented in table 2 replicates the cross-sectional approach taken in much of the previous literature on unemployment on health (for example Turner 1995, Rodriguez 2001, Artazcoz et al. 2004). In line with previous studies, I find a significant negative association between unemployment status and self-reported health. However, this does not establish a causal link from unemployment to ill health, if people who are ill in the first place are also more likely to become and/ or remain unemployed.

The coefficient of the effect of unemployment on health is 0.17 . Coefficients from ordered probit estimations don't have a straightforward intuitive interpretation. The estimated probability that an individual $i$ with exogenous characteristics $X_{i}$ falls in health category $j$ is given by:

$$
\operatorname{Prob}\left(\text { health }=j \mid X_{i}\right)=\Phi\left(\text { cutoff }_{j}-X_{i}^{\prime} \beta\right)-\Phi\left(\text { cutoff }_{j-1}-X_{i}^{\prime} \beta\right)
$$

The cutoff points are estimated together with the parameter coefficients $\beta$. $\Phi$ is the cumulative distribution function of a standard normal distribution. The marginal effect of an increase in an independent variable $x_{i k} \in X_{i}$ on the probability of outcome $j$ can be calculated by: $\delta(\operatorname{Prob}($ health $=j)) / \delta x_{i k}$. The size of the marginal effect of unemployment on health varies with the values of the other explanatory variables. Since the coefficient of unemployment is positive, unemployment increases the probability of higher health categories, which represent worse health.

The signs of the other dependent variables are as one might expect. Higher education, income and wealth are associated with better health, while higher age, smoking and obesity correlate with worse health.

\section{B. The average effect of job loss on health}

Table 3 shows the estimated average effect of job loss due to business closure on health. The table shows estimation results for various sets of covariates. This is a simple test to determine how unobserved heterogeneity can influence the estimated effect of business closure on health. If the effect of job loss on health is estimated without 
covariates or with only the probability of job loss, age, gender, and race as covariates, then the coefficient of business closure is significantly negative. However, if variables that account for differences in social status, health behaviors, and community characteristics are added to the regression, then the coefficient of the business closure variable diminishes in size and becomes insignificant. The subjective probability of job loss is associated with a significant subsequent deterioration in health. This can be explained either if the risk of being laid off itself is harmful to health, or if the subjective probability of job loss is correlated with other characteristics that cause ill health. Table 3 shows a small negative effect of higher county unemployment rates, and a small positive effect of higher county median household income. However, these coefficients are insignificant. The signs of the coefficients for the other covariates are mostly as expected. Higher education, income, and wealth have a positive effect on health change, while smoking and obesity are associated with worsening health.

Table 4 compares how subsequent health change varies for various reasons of job termination. Previous studies differ in what reasons for unemployment they include in their analysis. For example, Bjorklund (1985) and Rodriguez et al. (1999) include all reasons for unemployment, while Catalano et al. (2000) include only those who were involuntarily laid off. A simple test on how the definition of job loss influences the estimated effects of job loss on health is to estimate the effect of job loss on health for various reasons of job termination and compare the results. As discussed above, I assume that business closure is exogenous to health change, while being laid off, quitting, and leaving for health reasons might be endogenous. I find that being laid off, which could be for any reason, has a positive effect on health. While this result is somewhat surprising, a possible explanation is that lay-offs could occur as a reaction to work absences caused by acute illnesses that subsequently improve. There is no significant change in health for people who quit their job. However, people who leave their job for health reasons experience a very strong negative change in their health. As shown in table 1, leaving a job for health reasons is also quite common in this age group. In summary, these results suggest that the subsequent change of health varies substantially for different reasons of job termination. This implies that reverse causality can bias estimation results if the reason for unemployment is not exogenous. 
Table 5 presents the effect of job loss for several measures of health change. This allows checking whether the results are robust for varying measures of health. For example, if results vary widely for self-reported health and other health measures this could be an indicator for justification bias. Previous studies use different measures of health. Rodriguez et al. (1999) use self-reported overall health, Catalano et al. (2000) use a score for mental health, and Bjorklund (1985) and Dew et al. (1992) rely on doctor diagnosed mental conditions. Measures of health change in table 5 include the change in limitations of activities in daily living, the change in longevity expectations, the change in the CESD score for mental health, and first incidence of doctor diagnosed mental health conditions. For all of these measures, I find no significant effect of job loss on health change. The change in ADL limitations is positively influenced by higher education and a higher county median household income, and negatively by obesity. Longevity expectations improve with higher county median household income. The CESD score deteriorates for smokers. First diagnosis of mental health problems is more likely for smokers and females.

Summing up the results in tables 3 and 5, I find no significant average treatment effect from job loss to ill health. One concern is that the sample size (148 individuals lose their job due to business closure) is insufficient to determine a significant effect. However, the result that there is no effect of job loss on health was confirmed for five different measures of health, and in column 3 of table 4, 188 observations of individuals who left their job for health reasons were enough to gain a large and significant estimation coefficient. If there was any sizable effect of job loss on health in my sample, then the estimation results should show a significant effect.

\section{Change in income, Loss of health Insurance, and new Employment}

Tables 6 and 7 show how the effect of job loss on health varies with the amount of income reduction, loss of health insurance, and new employment. The effect of job loss induced change in income, loss of health insurance and new employment is estimated by instrumental variables (IV) regression. The dependent variable is selfreported change in overall health. The instrumental variable regression ignores the 
discrete nature of the change of health variable. Table 6 presents the $1^{\text {st }}$ stage regression results, which estimate the percentage change in real income, health insurance status, and new employment for people affected by job loss. The percentage reduction in income increases with longer job tenure. The percentage reduction of income is less for people with health insurance, especially if provided by the spouses' employer, and for people with a higher share of their wage income as a share of total household income. The partial $\mathrm{R}^{2}$ above 0.02 and the $\mathrm{F}$ statistic for the excluded instruments above 20 suggest that the instruments are not weak.

Individuals, whose wage accounted for a higher share of total household income, are more likely to work again after job loss, and so are individuals with employer provided health insurance. Having a spouse, who participates in an employer-sponsored health insurance plan, also increases the likelihood of working again. However, people with longer job tenure and people who are covered by government health insurance or by health insurance provided by their spouses' employer are less likely to work again. The partial $\mathrm{R}^{2}$ is above 0.13 and the F-statistic for the excluded instruments is above 130, which indicates that the instruments are not weak.

Being covered by health insurance after job loss is more likely for people who were covered before job loss, especially if they were covered by their spouses' employer or by government health insurance. If a spouse is also covered by an employers' health insurance plan, this increases the chances of having health insurance after job loss. People with longer job tenure and higher wage income as a share of total household income are also more likely to have insurance after the job loss. As before, a partial $\mathrm{R}^{2}$ above .15 and a F-statistic for the excluded instruments over 150 suggest that the instruments are not weak.

Table 7 presents the $2^{\text {nd }}$ stage results of the IV regressions, as well as the corresponding least square results that do not account for the endogeneity of change in income, new employment and health insurance to the change in health. In the least squares regression results, work after job loss is associated with improving health. However, if better health induces more labor supply then one would expect this estimate to be biased in the direction of improving health. Change in income and health insurance 
after job loss have no significant effect on health change in the least squares specification. After accounting for the endogeneity, the estimated effect of work on health becomes insignificant. Likewise, the effect of the percentage change in real income and the effect of health insurance after job loss are not significantly different from zero. Smoking and the subjective probability of job loss are associated with deteriorating health, while higher income is associated with better health. The Hansen JStatistic, which tests for the exogeneity of the instruments, has a p-value of 0.56 so that the $\mathrm{H}^{0}$ hypothesis that the instruments are exogenous is clearly not rejected.

In summary, this study finds no effect of a drop in income, loss of health insurance and of working again after job loss. The next section tests the possibility that some groups such as for example married men or college graduates are affected more by job loss than others, so that there might be a significant effect at least for some subgroups of people affected by job loss.

\section{Demographics, Job characteristics, and Spousal Job Loss}

The first column in table 8 shows the regression results if business closed is interacted with gender and marital status as well as education level. The omitted reference group would be unmarried females without high school degree. The results suggest that unmarried males and more educated people might be less affected by the negative health consequences of job loss. However, these differences are not significant.

The second row shows the regression results if the 'businessclosed' variable is interacted with previous job characteristics, for example for jobs that involve a lot of stress or a lot of physical effort or are poorly paid. The coefficients suggest that job losers whose previous job involved more physical effort, and was poorly paid, might suffer more in their health, but this effect is not significant. One interesting result is that people who state that their job is very stressful gain in their health. This can be explained if jobs that are labeled to be stressful often also involve more responsibility and a high degree of control.

The third column in table 8 shows how the effect of job loss varies with prior expectations about job loss. The variable 'unexpected' is defined as one minus the subjective probability of job loss. The table shows the effect of this variable both for 
people who were laid off, and for people who were not laid off. There is no significant effect for people who were laid off, but for people who were not laid off health improved with higher job security. Since we already found before that the subjective probability of job loss is associated with worsening health (for the entire sample), this is not a surprising result.

The last column of table 8 reports the effects of a spousal job loss on health. I find no significant effect, either of spousal job loss due to business closing or of the spouses' subjective probability of job loss.

\section{Conclusion}

In summary, I find no evidence of any effects of job loss on health within a period of up to two years after job loss. This result is robust across specification. It holds for various measures of physical and mental health, for the average effect of job loss on health for all laid off persons, as well as for the effect of job loss on specific groups defined by gender, marital status, education, and previous working conditions. There is also no effect of the job loss of a spouse.

This result contradicts much of the previous literature that finds strong negative health consequences of unemployment. In contrast to most previous studies that use broader definitions of job loss, this study focuses on people who have lost their job for an exogenous reason - the closure of their previous employer's business. Like previous studies, I find a negative association between unemployment and health in cross-section estimation (Table 2), and also that the health of laid-off workers evolves unfavorably compared to the overall population (Column 1 of Table 3). But this effect diminishes in size and becomes insignificant after controlling for education, initial health behaviors, and other characteristics (Column 4 of Table 3). I also find that leaving a job for health reasons is both quite common in this age group, and associated with a rapid deterioration in health, and that being laid off for any reason could also be related to health reasons (Table 5). My results suggest that the inferior health of the unemployed compared to the employed could be explained by reverse causality.

This paper also contributes to the literature on the relationship between income and health, health insurance and health, and employment and health. Job loss is an 
exogenous event associated with a strong reduction in income, widespread loss of health insurance, and withdrawal from the labor force. It can be seen as a natural experiment that allows estimating the effects of income, health insurance and employment on health. In this study I find that job loss causes loss of income, health insurance, and withdrawal from the labor force, but that these factors have no effect on health.

\section{References}

Adams, Peter, Michael Hurd, Daniel McFadden, Angela Merrill, Tiago Ribeiro (2003), Healthy, wealthy, and wise? Tests for direct causal paths between health and socioeconomic status, Journal of Econometrics, 112, 3-56.

Arrow, J. O. (1996), Estimating the influence of health as a risk factor on unemployment: A survival analysis of employment duration for workers surveyed in the German Socio-Economic Panel, Social Science \& Medicine, 42 (12), 1651 - 1659.

Artazcoz, Lucia, Joan Benach, Carmen Borrell, Immaculada Cortes (2004), Unemployment and mental health: Understanding the interactions among gender, family roles and social class, American Journal of Public Health, 94 (1), 82 - 88.

Baum, Christopher, Mark Scheffer, and Steven Stillman (2003), Instrumental variables and GMM: Estimation and testing, Stata Journal, 3 (1), 1-31

Bjorklund, Andres (1985), Unemployment and mental health: Some evidence from panel data, Journal of Human Resources, 20 (4), $469-483$.

Blundell, Richard, and Thomas MaCurdy (1999), Labor Supply: A review of alternative approaches, Chapter 27 in: Handbook of Labor Economics, Vol. 3A, Edited by Orley Ashenfelter and David Card, Elsevier

Catalano, Ralph, Ethel Adrete, William Vega, Bohdan Kolody, and Sergio Aguila-Gaxiola (2000), Job loss and major depression among Mexican Americans, Social Science Quarterly, 81 (1), $477-487$.

Chan, Sewin, and Ann Stevens (2001), Job loss and employment patterns of older workers, Journal of Labor Economics, 19 (2), $484-521$. 
Chan, Sewin, and Ann Stevens (2002), How does job loss affect the timing of retirement? NBER Working Paper 8780.

Currie, Janet, and Brigitte C. Madrian (1999), Health, Health Insurance and the Labor Market, Chapter 50 in: Handbook of Labor economics, Vol. 3C, Edited by Orley Ashenfelter and David Card, Elsevier.

Dew, Mary A., Evelyn Bromet, and Lili Penkower (1992), Mental health effects of job loss in women, Psychological Medicine, 22, $751-764$.

Ettner, Susan (1996), New evidence on the relationship between income and health, Journal of Health Economics, 15, $67-85$.

Gerdtham, Ulf, and Magnus Johannesson (2003), A note on the effect of Unemployment on mortality, Journal of Health Economics, 22, 505 - 518

Haudley, Jack (2003), Sicker and Poorer- The consequences of Being Uninsured: A Review of the Research on the Relationship between Health Insurance, Medical Care Use, Health, Work, and Income, Medical Care Research and Review, Vol. 60 (2), Supplement, $3 \mathrm{~S}-75 \mathrm{~S}$

Heckman, James J., Hidehiko Ichimura, and Petra E. Todd (1997), Matching as an Econometric Evaluation Estimator: Evidence from Evaluating a Job Training Program, Review of Economic Studies, 64 (4), 605 - 654.

Idler, E., Y. Benyamini (1997), Self-related health and mortality: A Review of twenty-seven Community studies, Journal of Health and Social Behavior, 38, 21 -37.

Levy, Helen and David Meltzer (2004), What do we really know about whether health insurance affects health? in: Health Policy and the Uninsured, Edited by Catherine McLaughlin, Urban Institute Press.

Lindahl, Mikael (2005), Estimating the effect of income on health and mortality using lottery prizes as an exogenous source of variation in income, forthcoming in: Journal of Human Resources, 40 (1). 
Mayer, Francine, Paul-Marcel Roy, Aline Emond, and Raynald Pincault (1991), Unemployment and mental health: a longitudinal analysis, Canadian Journal of Economics, 24 (3), $551-562$.

McGarry, Kathleen (2004), Do Changes in Health Affect Retirement Expectations? Journal of Human Resources, 39 (3), $624-648$.

Meer, Jonathan, Douglas Miller, Harvey Rosen (2003), Exploring the Health Wealth Nexus, Journal of Health Economics, 22, $713-730$.

Meyer, Bruce D. (1995), Natural and Quasi- Experiments in Economics, Journal of Business \& Economics Statistics, 13 (2), 151 - 161

Price, Richard, Jin Choi, and Amiram Vinokur (2002), Links in the chain of adversity following job loss: How financial strain and loss of personal control lead to depression, impaired functioning, and poor health, Journal of Occupational Health Psychology, 7 (4), $302-312$.

Rodriguez, E., J. A. Allen, E. A. Frongillo, and J. and P. Chandra (1999), Unemployment, depression and health: A look at the African-American community, Journal of Epidemiology and Community Health, 53, 335 -342.

Rodriguez, Eunice (2001), Keeping the unemployed healthy: The effect of meanstested and entitlement benefits in Britain, Germany, and the United States, American Journal of Public Health, 91 (9), 1403 -1411

Ruhm, Christopher (1991), Displacement Induced Joblessness, Review of Economics and Statistics, 73 (3), $517-522$.

Ruhm, Christopher (2000), Are Recessions Good For Your Health?, Quarterly Journal of Economics, 115 (2), $617-650$.

Ruhm, Christopher (2005), Healthy living in hard times, Journal of Health Economics, 24, $341-363$.

Stephens, Melvin (2004), Job loss expectations, realizations, and household consumption behavior, Review of Economics and Statistics, 86 (1), 253 -269. 
Stevens, Ann (1997), Persistent effects of job displacement: The importance of multiple job losses, Journal of Labor Economics, 15 (1), 165 - 188.

Stewart, Jennifer (2001), The impact of health status on the duration of unemployment spells and the implications for studies of the impact of unemployment on health status, Journal of Health Economics, 20, 781 -796.

Turner, J. Blake (1995), Economic Context and the health effects of unemployment, Journal of Health and Social Behavior, 36 (3), 213 - 229. 


\section{Appendix}

Table 1: Sample Statistics

\begin{tabular}{|c|c|c|c|c|}
\hline & \multicolumn{2}{|c|}{ Entire Sample } & \multicolumn{2}{|c|}{ Business Closed } \\
\hline & Mean & Std. Dev. & Mean & Std. Dev. \\
\hline \multicolumn{5}{|l|}{ Health Measures } \\
\hline Health Change & 3.006 & $(0.711)$ & 3.135 & $(0.715)$ \\
\hline ADL Change & 0.060 & $(0.425)$ & 0.074 & $(0.535)$ \\
\hline Life Exp. Change & 0.003 & $(0.398)$ & 0.010 & $(0.429)$ \\
\hline CESD Change & 0.103 & $(1.925)$ & 0.413 & (2.393) \\
\hline Psych Diagnosis & 0.018 & $(0.133)$ & 0.047 & $(0.212)$ \\
\hline \multirow[t]{2}{*}{ Health } & 2.334 & $(0.983)$ & 2.371 & $(0.991)$ \\
\hline & \multicolumn{2}{|c|}{ Number Affected } & & \\
\hline \multicolumn{5}{|l|}{ Reasons for Job termination } \\
\hline Business Closed & \multicolumn{2}{|l|}{148} & & \\
\hline Laid Off & \multicolumn{2}{|l|}{277} & & \\
\hline Quit & \multicolumn{2}{|l|}{219} & & \\
\hline Left for Health & \multicolumn{2}{|l|}{188} & & \\
\hline \multirow[t]{3}{*}{ Spouse Business Closed } & \multicolumn{2}{|l|}{85} & & \\
\hline & \multicolumn{2}{|c|}{ Entire Sample } & \multicolumn{2}{|c|}{ Business Closed } \\
\hline & Mean & Std. Dev. & Mean & Std. Dev. \\
\hline Prob. Of Job Loss & 14.9 & $(24.4)$ & 32.5 & $(35.1$ \\
\hline Spouse Prob. of Job Loss & 14.3 & $(24.1)$ & & \\
\hline \multicolumn{5}{|l|}{ Demographics } \\
\hline Age & 54.1 & $(5.01)$ & 53.9 & $(4.01)$ \\
\hline Female & 0.577 & $(0.493)$ & 0.621 & $(0.486)$ \\
\hline Black & 0.149 & $(0.356)$ & 0.094 & $(0.293)$ \\
\hline Married & 0.758 & $(0.428)$ & 0.783 & $(0.413)$ \\
\hline Married Male & 0.354 & $(0.478)$ & 0.317 & $(0.467)$ \\
\hline Married Female & 0.400 & $(0.490)$ & 0.466 & $(0.500)$ \\
\hline Not Married Male & 0.068 & $(0.251)$ & 0.060 & $(0.239)$ \\
\hline \multicolumn{5}{|l|}{ Social Status } \\
\hline High School & 0.559 & $(0.496)$ & 0.601 & $(0.491)$ \\
\hline College & 0.231 & $(0.422)$ & 0.094 & $(0.293)$ \\
\hline Income & 9.439 & $(0.898)$ & 9.278 & $(0.736)$ \\
\hline Wealth & 58893 & $(110907)$ & 36830 & (45234) \\
\hline \multicolumn{5}{|l|}{ Community Characteristics } \\
\hline County Unemployment & 5.6 & $(2.65)$ & 6.2 & (3.2) \\
\hline County Income & 37624 & (9749) & 37122 & (9976) \\
\hline \multicolumn{5}{|l|}{ Health Behaviors } \\
\hline Smoking & 0.237 & $(0.425)$ & 0.344 & $(0.47685)$ \\
\hline High BMI & 0.246 & $(0.430)$ & 0.297 & $(0.458)$ \\
\hline Health Insurance & 0.925 & $(0.262)$ & 0.891 & $(0.311)$ \\
\hline Number of Observation in Base & 5985 & & 148 & \\
\hline
\end{tabular}




\begin{tabular}{lrrrr}
\hline & \multicolumn{3}{c}{ Entire Sample } & \multicolumn{2}{c}{ Business Closed } \\
& Mean & Std. Dev. & Mean & Std. Dev. \\
\hline Endogenous Variables & & & & \\
Income Change & 0.050 & $(0.698)$ & -0.158 & $(0.756)$ \\
Work at 2 ${ }^{\text {nd }}$ Interview & 0.829 & $(0.375)$ & 0.567 & $(0.497)$ \\
Health Insurance at 2 ${ }^{\text {nd }}$ Interview & 0.927 & $(0.259)$ & 0.777 & $(0.417)$ \\
Instrumental variables & & & & \\
Job Tenure & 13.1 & $(10.6)$ & 8.7 & $(9.3)$ \\
Spouse Education & 12.6 & $(2.9)$ & 11.8 & $(3.3)$ \\
Government Health Insurance & 0.055 & $(0.228)$ & 0.067 & $(0.251)$ \\
Employer Health Insurance & 0.682 & $(0.465)$ & 0.533 & $(0.500)$ \\
Spouse Health Insurance & 0.207 & $(0.405)$ & 0.270 & $(0.445)$ \\
Individual Health Insurance & 0.074 & $(0.261)$ & 0.101 & $(0.302)$ \\
Spouse own Health Insurance & 0.338 & $(0.473)$ & 0.378 & $(0.486)$ \\
Wage/ Income Ratio & 0.589 & $(0.300)$ & 0.542 & $(0.334)$ \\
Manager or Professional & 0.336 & $(0.472)$ & 0.189 & $(0.392)$ \\
Prob. Work to 65 & 22.7 & $(30.9)$ & 22.8 & $(30.842)$ \\
Job Characteristics & & & & \\
Job Physical Effort & 2.76 & $(1.12)$ & 2.61 & $(1.15)$ \\
Job Stressful & 2.17 & $(0.80)$ & 2.31 & $(0.82)$ \\
Low Wage & 0.172 & $(0.377)$ & 0.306 & $(0.46)$ \\
\hline Number of observations in baseline & 5985 & & 148 & \\
& & & &
\end{tabular}


Table 2: Cross- Section Regression of Health on Unemployment

\begin{tabular}{ll}
\hline & \multicolumn{1}{c}{ Health } \\
\hline Unemployed & $0.171^{* *}$ \\
Age & $(0.073)$ \\
& $0.017^{* * *}$ \\
Female & $(0.003)$ \\
& -0.002 \\
Black & $(0.025)$ \\
& $0.179^{* * *}$ \\
Married & $(0.034)$ \\
& -0.025 \\
High School & $(0.030)$ \\
& $-0.348^{* * *}$ \\
College & $(0.031)$ \\
& $-0.593^{* * *}$ \\
Income & $(0.040)$ \\
& $-0.157^{* * *}$ \\
Wealth & $(0.016)$ \\
& -0.011 \\
Smoking & $(0.010)$ \\
& $0.18^{* * *}$ \\
High BMI & $(0.028)$ \\
& $0.409^{* * *}$ \\
Health Insurance & $(0.028)$ \\
& -0.011 \\
Observations & $(0.042)$ \\
Pseudo R- Squared & 0.05 \\
\hline Robust standard errors in brackets \\
* significant at 10\%; ** significant at $5 \% ; * *$ significant at 1\% \\
Coefficients for binary & wave variables not shown \\
Ordered Probit estimation & \\
Higher values for health represent worse health & \\
&
\end{tabular}


Table 3: The causal Effect of Job Loss on Health

\begin{tabular}{|c|c|c|c|c|}
\hline & $\begin{array}{c}\text { Health } \\
\text { Change }\end{array}$ & $\begin{array}{c}\text { Health } \\
\text { Change }\end{array}$ & $\begin{array}{c}\text { Health } \\
\text { Change }\end{array}$ & $\begin{array}{l}\text { Health } \\
\text { Change }\end{array}$ \\
\hline Business Closed & $\begin{array}{l}0.173^{* *} \\
(0.087)\end{array}$ & $\begin{array}{l}0.176^{*} \\
(0.097)\end{array}$ & $\begin{array}{l}0.136 \\
(0.098)\end{array}$ & $\begin{array}{l}0.119 \\
(0.099)\end{array}$ \\
\hline Prob. Of Job Loss & & $\begin{array}{l}0.002^{* * *} \\
(0.001)\end{array}$ & $\begin{array}{l}0.002^{* * *} \\
(0.001)\end{array}$ & $\begin{array}{l}0.002^{* *} \\
(0.001)\end{array}$ \\
\hline Age & & $\begin{array}{l}0.004 \\
(0.003)\end{array}$ & $\begin{array}{l}0.004 \\
(0.003)\end{array}$ & $\begin{array}{l}0.005 \\
(0.003)\end{array}$ \\
\hline Black & & $\begin{array}{l}-0.063 \\
(0.043)\end{array}$ & $\begin{array}{l}-0.114^{\star *} \\
(0.044)\end{array}$ & $\begin{array}{l}-0.133^{* * *} \\
(0.045)\end{array}$ \\
\hline Female & & $\begin{array}{l}0.01 \\
(0.031)\end{array}$ & $\begin{array}{l}0.019 \\
(0.032)\end{array}$ & $\begin{array}{l}0.029 \\
(0.032)\end{array}$ \\
\hline Married & & & $\begin{array}{l}0.034 \\
(0.038)\end{array}$ & $\begin{array}{l}0.056 \\
(0.039)\end{array}$ \\
\hline High School & & & $\begin{array}{l}-0.141^{* * *} \\
(0.042)\end{array}$ & $\begin{array}{l}-0.118^{* \star *} \\
(0.043)\end{array}$ \\
\hline College & & & $\begin{array}{l}-0.185^{\star * *} \\
(0.050)\end{array}$ & $\begin{array}{l}-0.139^{* * *} \\
(0.052)\end{array}$ \\
\hline Income & & & $\begin{array}{l}-0.046^{* *} \\
(0.021)\end{array}$ & $\begin{array}{l}-0.041^{*} \\
(0.022)\end{array}$ \\
\hline Wealth & & & $\begin{array}{l}-0.027^{*} \\
(0.014)\end{array}$ & $\begin{array}{l}-0.024^{*} \\
(0.014)\end{array}$ \\
\hline County Unemployment & & & $\begin{array}{l}0.001 \\
(0.007)\end{array}$ & $\begin{array}{l}0.001 \\
(0.007)\end{array}$ \\
\hline County Income & & & $\begin{array}{l}-0.106 \\
(0.178)\end{array}$ & $\begin{array}{l}-0.085 \\
(0.177)\end{array}$ \\
\hline Smoking & & & & $\begin{array}{l}0.144^{* * *} \\
(0.038)\end{array}$ \\
\hline High BMI & & & & $\begin{array}{l}0.129^{* * *} \\
(0.038)\end{array}$ \\
\hline Health Insurance & & & & $\begin{array}{l}0.057 \\
(0.065)\end{array}$ \\
\hline Observations & 7997 & 6120 & 5986 & 5985 \\
\hline Pseudo R-Squared & 0.0003 & 0.0019 & 0.005 & 0.007 \\
\hline
\end{tabular}

Robust standard errors in brackets

${ }^{*}$ significant at $10 \%$; ${ }^{* *}$ significant at $5 \%$; ${ }^{* * *}$ significant at $1 \%$

Coefficents for binary Wave Variables not shown

All columns are Ordered Probit Estimations

Higher values for health change represent worsening health 
Table 4: Endogenous Causes of Job Termination

\begin{tabular}{|c|c|c|c|}
\hline & $\begin{array}{c}\text { Health } \\
\text { Change }\end{array}$ & $\begin{array}{c}\text { Health } \\
\text { Change }\end{array}$ & $\begin{array}{l}\text { Health } \\
\text { Change }\end{array}$ \\
\hline Laid Off & $\begin{array}{l}-0.135^{*} \\
(0.078)\end{array}$ & & \\
\hline Quit & & $\begin{array}{l}-0.111 \\
(0.087)\end{array}$ & \\
\hline Left for Health & & & $\begin{array}{l}1.28^{\star * *} \\
(0.106)\end{array}$ \\
\hline Prob. of Job Loss & $\begin{array}{l}0.002^{* * *} \\
(0.001)\end{array}$ & $\begin{array}{l}0.002^{* * *} \\
(0.001)\end{array}$ & $\begin{array}{l}0.001^{* *} \\
(0.001)\end{array}$ \\
\hline Age & $\begin{array}{l}0.005 \\
(0.003)\end{array}$ & $\begin{array}{l}0.005 \\
(0.003)\end{array}$ & $\begin{array}{l}0.004 \\
(0.003)\end{array}$ \\
\hline Female & $\begin{array}{l}0.028 \\
(0.032)\end{array}$ & $\begin{array}{l}0.03 \\
(0.032)\end{array}$ & $\begin{array}{l}0.02 \\
(0.032)\end{array}$ \\
\hline Black & $\begin{array}{l}-0.137^{* * *} \\
(0.045)\end{array}$ & $\begin{array}{l}-0.136^{* * *} \\
(0.045)\end{array}$ & $\begin{array}{l}-0.14^{* * *} \\
(0.044)\end{array}$ \\
\hline Married & $\begin{array}{l}0.056 \\
(0.039)\end{array}$ & $\begin{array}{l}0.057 \\
(0.039)\end{array}$ & $\begin{array}{l}0.063 \\
(0.039)\end{array}$ \\
\hline High School & $\begin{array}{l}-0.118^{* * *} \\
(0.043)\end{array}$ & $\begin{array}{l}-0.118^{* * *} \\
(0.043)\end{array}$ & $\begin{array}{l}-0.071^{*} \\
(0.043)\end{array}$ \\
\hline College & $\begin{array}{l}-0.141^{* * *} \\
(0.052)\end{array}$ & $\begin{array}{l}-0.139^{* * *} \\
(0.052)\end{array}$ & $\begin{array}{l}-0.085 \\
(0.052)\end{array}$ \\
\hline Income & $\begin{array}{l}-0.041^{*} \\
(0.022)\end{array}$ & $\begin{array}{l}-0.041^{*} \\
(0.022)\end{array}$ & $\begin{array}{l}-0.03 \\
(0.021)\end{array}$ \\
\hline Wealth & $\begin{array}{l}-0.024^{*} \\
(0.014)\end{array}$ & $\begin{array}{l}-0.024^{*} \\
(0.014)\end{array}$ & $\begin{array}{l}-0.026^{*} \\
(0.014)\end{array}$ \\
\hline County Unemployment & $\begin{array}{l}0.002 \\
(0.007)\end{array}$ & $\begin{array}{l}0.001 \\
(0.007)\end{array}$ & $\begin{array}{l}0.003 \\
(0.007)\end{array}$ \\
\hline County Income & $\begin{array}{l}-0.072 \\
(0.177)\end{array}$ & $\begin{array}{l}-0.084 \\
(0.177)\end{array}$ & $\begin{array}{l}-0.015 \\
(0.178)\end{array}$ \\
\hline Smoking & $\begin{array}{l}0.147^{* * *} \\
(0.038)\end{array}$ & $\begin{array}{l}0.148^{* * *} \\
(0.038)\end{array}$ & $\begin{array}{l}0.135^{\star * *} \\
(0.038)\end{array}$ \\
\hline High BMI & $\begin{array}{l}0.13^{* * *} \\
(0.038)\end{array}$ & $\begin{array}{l}0.129^{* * *} \\
(0.038)\end{array}$ & $\begin{array}{l}0.114^{* * *} \\
(0.038)\end{array}$ \\
\hline Health Insurance & $\begin{array}{l}0.053 \\
(0.065)\end{array}$ & $\begin{array}{l}0.053 \\
(0.066)\end{array}$ & $\begin{array}{l}0.066 \\
(0.065)\end{array}$ \\
\hline Observations & 5985 & 5985 & 5985 \\
\hline Pseudo R- Squared & 0.007 & 0.007 & 0.029 \\
\hline
\end{tabular}

Robust standard errors in brackets

* significant at $10 \%$; ${ }^{* *}$ significant at $5 \%$; ${ }^{* * *}$ significant at $1 \%$

Coefficients for binary wave variables not shown

All columns are Ordered Probit estimations

Higher values for health change represent worsening health 
Table 5: Alternative Measures of Health

\begin{tabular}{|c|c|c|c|c|}
\hline & ADL Change & $\begin{array}{l}\text { Life Exp. } \\
\text { Change }\end{array}$ & $\begin{array}{c}\text { CESD } \\
\text { Change }\end{array}$ & $\begin{array}{c}\text { First Psych } \\
\text { Diagnosis }\end{array}$ \\
\hline \multirow[t]{2}{*}{ Business Closed } & -0.056 & 0.014 & 0.297 & 0.028 \\
\hline & $(0.160)$ & $(0.038)$ & $(0.197)$ & $(0.019)$ \\
\hline \multirow[t]{2}{*}{ Prob. of Job Loss } & 0.001 & -0.0002 & -0.0003 & $0.0001^{*}$ \\
\hline & $(0.001)$ & $(0.000)$ & $(0.001)$ & $(0.000)$ \\
\hline \multirow[t]{2}{*}{ Age } & -0.005 & -0.0002 & 0.003 & -0.001 \\
\hline & $(0.005)$ & $(0.001)$ & $(0.006)$ & $(0.000)$ \\
\hline \multirow[t]{2}{*}{ Female } & 0.056 & 0.011 & -0.021 & $0.011^{* * *}$ \\
\hline & $(0.047)$ & $(0.012)$ & $(0.052)$ & $(0.004)$ \\
\hline \multirow[t]{2}{*}{ Black } & 0.008 & -0.017 & 0.009 & $-0.015^{* * *}$ \\
\hline & $(0.070)$ & $(0.018)$ & $(0.075)$ & $(0.005)$ \\
\hline \multirow[t]{2}{*}{ Married } & -0.016 & 0.012 & -0.012 & -0.004 \\
\hline & $(0.057)$ & $(0.013)$ & $(0.066)$ & $(0.005)$ \\
\hline \multirow[t]{2}{*}{ High School } & $-0.188^{* * *}$ & 0.004 & 0.066 & $-0.011^{* *}$ \\
\hline & $(0.064)$ & $(0.018)$ & $(0.076)$ & $(0.005)$ \\
\hline \multirow[t]{2}{*}{ College } & $-0.236^{* * *}$ & 0.021 & 0.005 & -0.009 \\
\hline & $(0.075)$ & $(0.020)$ & $(0.085)$ & $(0.006)$ \\
\hline \multirow[t]{2}{*}{ Income } & -0.033 & 0.008 & -0.03 & 0.001 \\
\hline & $(0.031)$ & $(0.008)$ & $(0.038)$ & $(0.002)$ \\
\hline \multirow[t]{2}{*}{ Wealth } & -0.013 & 0.005 & 0.001 & 0.001 \\
\hline & $(0.014)$ & $(0.005)$ & $(0.020)$ & $(0.002)$ \\
\hline \multicolumn{2}{|c|}{ County Unemployment-0.017 } & -0.001 & $-0.023^{*}$ & -0.001 \\
\hline & $(0.011)$ & $(0.003)$ & $(0.012)$ & $(0.001)$ \\
\hline \multirow[t]{2}{*}{ County Income } & $-0.509^{*}$ & $-0.107^{*}$ & -0.363 & $-0.041^{*}$ \\
\hline & $(0.269)$ & $(0.060)$ & $(0.299)$ & $(0.021)$ \\
\hline \multirow[t]{2}{*}{ Smoking } & 0.068 & -0.003 & $0.159^{* *}$ & $0.014^{* * *}$ \\
\hline & $(0.056)$ & $(0.014)$ & $(0.065)$ & $(0.005)$ \\
\hline \multirow[t]{2}{*}{ High BMI } & $0.198^{\star * *}$ & -0.018 & 0.083 & 0.007 \\
\hline & $(0.057)$ & $(0.013)$ & $(0.062)$ & $(0.005)$ \\
\hline \multirow{2}{*}{ Health Insurance } & 0.061 & -0.02 & $0.209^{*}$ & 0.009 \\
\hline & $(0.101)$ & $(0.024)$ & $(0.112)$ & $(0.007)$ \\
\hline Observations & 5984 & 5456 & 5867 & 5586 \\
\hline (Pseudo) R-squared & 0.02 & 0.01 & 0.01 & 0.01 \\
\hline
\end{tabular}

Robust standard errors in brackets

* significant at $10 \%$; ${ }^{* *}$ significant at $5 \%$; ${ }^{* * *}$ significant at $1 \%$

Coefficents for Wave Variables not shown

Column (1) is Ordered Probit Regression

Columns (2) to (4) are Least Square Regressions 
Table 6: Effect of Income Change, Health insurance and Re-Employment for Individuals affected by Business Closure: $1^{\text {St }}$ Stage

\begin{tabular}{|c|c|c|c|}
\hline & $\begin{array}{l}\text { Income } \\
\text { Change } \\
\times \text { Business } \\
\text { Closed }\end{array}$ & $\begin{array}{l}\text { Work at } 2^{\text {nd }} \\
\text { Interview } \\
\times \text { Business } \\
\text { Closed }\end{array}$ & $\begin{array}{l}\text { Health } \\
\text { Insurance at } \\
2^{\text {nd }} \text { Interview } \\
\times \text { Business } \\
\text { Closed }\end{array}$ \\
\hline Job Tenure $\times$ Business Closed & $\begin{array}{l}-0.004^{* * *} \\
(0.001)\end{array}$ & $\begin{array}{l}-0.012^{* * *} \\
(0.0006)\end{array}$ & $\begin{array}{l}0.003^{* \star *} \\
(0.0005)\end{array}$ \\
\hline $\begin{array}{l}\text { Wage/ Income Ratio } \\
\times \text { Business Closed }\end{array}$ & $\begin{array}{l}0.114^{\star * *} \\
(0.033)\end{array}$ & $\begin{array}{l}0.363^{* * *} \\
(0.020)\end{array}$ & $\begin{array}{l}0.110^{* * *} \\
(0.017)\end{array}$ \\
\hline $\begin{array}{l}\text { Spouse own Health Insurance } \\
\times \text { Business Closed }\end{array}$ & $\begin{array}{l}-0.052^{*} \\
(0.027)\end{array}$ & $\begin{array}{l}0.240^{* * *} \\
(0.017)\end{array}$ & $\begin{array}{l}0.191^{* * *} \\
(0.014)\end{array}$ \\
\hline $\begin{array}{l}\text { Government Health Insurance } \\
\times \text { Business Closed }\end{array}$ & $\begin{array}{l}0.174^{* * *} \\
(0.040)\end{array}$ & $\begin{array}{l}-0.216^{* * *} \\
(0.024)\end{array}$ & $\begin{array}{l}0.293^{* * *} \\
(0.019)\end{array}$ \\
\hline $\begin{array}{l}\text { Employer Health Insurance } \\
\times \text { Business Closed }\end{array}$ & $\begin{array}{l}0.207^{\star * \star} \\
(0.028)\end{array}$ & $\begin{array}{l}0.128^{* \star *} \\
(0.017)\end{array}$ & $\begin{array}{l}0.235^{\star * *} \\
(0.014)\end{array}$ \\
\hline $\begin{array}{l}\text { Spouse Health Insurance } \\
\times \text { Business Closed }\end{array}$ & $\begin{array}{l}0.418^{* * *} \\
(0.037)\end{array}$ & $\begin{array}{l}-0.050^{* *} \\
(0.023)\end{array}$ & $\begin{array}{l}0.293^{* * *} \\
(0.019)\end{array}$ \\
\hline $\begin{array}{l}\text { Individual Health Insurance } \\
\times \text { Business Closed }\end{array}$ & $\begin{array}{l}0.224^{* * *} \\
(0.036)\end{array}$ & $\begin{array}{l}0.020 \\
(0.022)\end{array}$ & $\begin{array}{l}0.211^{* * *} \\
(0.018)\end{array}$ \\
\hline Observations & 5931 & 5931 & 5931 \\
\hline R-squared & 0.07 & 0.62 & 0.80 \\
\hline Patial R-squared & 0.02 & 0.13 & 0.15 \\
\hline F-Statistic of excluded Instruments & 22.5 & 134.6 & 156.2 \\
\hline
\end{tabular}

Robust standard errors in brackets

${ }^{*}$ significant at $10 \%$; ${ }^{* *}$ significant at $5 \%$; ${ }^{* * *}$ significant at $1 \%$

Coefficients for Variables in Baseline Regression (table 3, column 4) and Waves not shown

All columns are Least Squares Estimations 
Table 7: Effect of Income Change, Health insurance and Re-Employment for Individuals affected by Business Closure: $2^{\text {nd }}$ Stage

\begin{tabular}{|c|c|c|}
\hline & $\begin{array}{c}\text { Health Change } \\
\text { IV }\end{array}$ & $\begin{array}{c}\text { Health Change } \\
\text { OLS }\end{array}$ \\
\hline Income Change & -0.480 & 0.016 \\
\hline$\times$ Business Closed & $(0.832)$ & $(0.089)$ \\
\hline Work at $2^{\text {nd }} \mathrm{IW}$ & -0.346 & $-0.30^{* * *}$ \\
\hline$\times$ Business Closed & $(0.381)$ & $(0.115)$ \\
\hline Health Insurance at $2^{\text {nd }}$ IW & 0.893 & 0.076 \\
\hline$\times$ Business Closed & $(0.647)$ & $(0.137)$ \\
\hline \multirow[t]{2}{*}{ Business Closed } & -0.485 & 0.206 \\
\hline & $(0.674)$ & $(0.158)$ \\
\hline \multirow[t]{2}{*}{ Prob. of Job Loss } & $0.0007^{*}$ & $0.0008^{* *}$ \\
\hline & $(0.0004)$ & $(0.0004)$ \\
\hline \multirow[t]{2}{*}{ Age } & 0.002 & 0.002 \\
\hline & $(0.002)$ & $(0.002)$ \\
\hline \multirow[t]{2}{*}{ Female } & 0.008 & 0.012 \\
\hline & $(0.019)$ & $(0.019)$ \\
\hline \multirow[t]{2}{*}{ Black } & $-0.080^{* * *}$ & $-0.076^{* * *}$ \\
\hline & $(0.028)$ & $(0.027)$ \\
\hline \multirow[t]{2}{*}{ Married } & 0.027 & 0.028 \\
\hline & $(0.023)$ & $(0.023)$ \\
\hline \multirow[t]{2}{*}{ High School } & $-0.069^{* * *}$ & $-0.066^{\star *}$ \\
\hline & $(0.026)$ & $(0.026)$ \\
\hline \multirow[t]{2}{*}{ College } & $-0.077^{* *}$ & $-0.076^{* *}$ \\
\hline & $(0.031)$ & $(0.031)$ \\
\hline \multirow[t]{2}{*}{ Income } & $-0.023^{* *}$ & -0.02 \\
\hline & $(0.013)$ & $(0.013)$ \\
\hline \multirow[t]{2}{*}{ Wealth } & -0.014 & -0.014 \\
\hline & $(0.009)$ & $(0.009)$ \\
\hline \multirow[t]{2}{*}{ County Unemployment } & -0.0008 & -0.0003 \\
\hline & $(0.004)$ & $(0.004)$ \\
\hline \multirow[t]{2}{*}{ County Income } & -0.057 & -0.043 \\
\hline & $(0.107)$ & $(0.106)$ \\
\hline \multirow[t]{2}{*}{ Smoking } & $0.087^{* * *}$ & $0.085^{* * *}$ \\
\hline & $(0.022)$ & $(0.022)$ \\
\hline \multirow[t]{2}{*}{ High BMI } & 0.068 & $0.067^{* * *}$ \\
\hline & $(0.023)^{\star * *}$ & $(0.023)$ \\
\hline \multirow[t]{2}{*}{ Health Insurance } & 0.051 & 0.055 \\
\hline & $(0.041)$ & $(0.041)$ \\
\hline Observations & 5931 & 5931 \\
\hline R-squared & & 0.01 \\
\hline Hansen J (P- Value) & 0.851 & \\
\hline \multicolumn{3}{|c|}{ Robust standard errors in brackets } \\
\hline
\end{tabular}


Table 8: Effects of Job Loss interacted with Social Characteristics, previous Job

\section{Characteristics, Job Loss Expectations, and Spousal Job Loss}

\begin{tabular}{|c|c|c|c|c|}
\hline & $\begin{array}{c}\text { Health } \\
\text { Change }\end{array}$ & $\begin{array}{l}\text { Health } \\
\text { Change }\end{array}$ & $\begin{array}{l}\text { Health } \\
\text { Change }\end{array}$ & $\begin{array}{c}\text { Health } \\
\text { Change }\end{array}$ \\
\hline \multirow[t]{2}{*}{ Business Closed } & 0.32 & -0.278 & 0.153 & \\
\hline & $(0.359)$ & $(0.384)$ & $(0.126)$ & \\
\hline \multirow[t]{2}{*}{ Prob. Of Job Loss } & $0.002^{* *}$ & $0.002^{* *}$ & & \\
\hline & $(0.001)$ & $(0.001)$ & & \\
\hline Married Male & 0.121 & & & \\
\hline$\times$ Business Closed & $(0.313)$ & & & \\
\hline Married Female & -0.083 & & & \\
\hline$\times$ Business Closed & $(0.311)$ & & & \\
\hline Not Married Male & -0.375 & & & \\
\hline$\times$ Business Closed & $(0.471)$ & & & \\
\hline \multirow[t]{2}{*}{ Black $\times$ Business Closed } & 0.184 & & & \\
\hline & $(0.364)$ & & & \\
\hline High School & -0.261 & & & \\
\hline$\times$ Business Closed & $(0.233)$ & & & \\
\hline College & -0.403 & & & \\
\hline$\times$ Business Closed & $(0.327)$ & & & \\
\hline Job Stressful & & 0.034 & & \\
\hline$\times$ Business Closed & & $(0.123)$ & & \\
\hline Job Physical Effort & & 0.103 & & \\
\hline$\times$ Business Closed & & $(0.084)$ & & \\
\hline Low Wage & & 0.314 & & \\
\hline$\times$ Business Closed & & $(0.239)$ & & \\
\hline Job Stressful & & $-0.069^{* * *}$ & & \\
\hline$\times$ Business Closed & & $(0.021)$ & & \\
\hline Job Physical Effort & & -0.014 & & \\
\hline$\times$ Business Closed & & $(0.016)$ & & \\
\hline Low Wage & & 0.011 & & \\
\hline$\times$ Business Closed & & $(0.051)$ & & \\
\hline Unexpected & & & -0.001 & \\
\hline$\times$ Business Closed & & & $(0.003)$ & \\
\hline \multirow[t]{2}{*}{ Unexpected } & & & $-0.002^{* *}$ & \\
\hline & & & $(0.001)$ & \\
\hline \multirow[t]{2}{*}{ Spouse Business Closed } & & & & 0.145 \\
\hline & & & & $(0.133)$ \\
\hline \multirow[t]{2}{*}{ Spouse Prob. of Job Loss } & & & & 0.001 \\
\hline & & & & $(0.001)$ \\
\hline Observations & 5985 & 5559 & 5985 & 3230 \\
\hline Pseudo R- Squared & 0.008 & 0.01 & 0.008 & 0.006 \\
\hline
\end{tabular}

Robust standard errors in brackets

${ }^{*}$ significant at $10 \%$; ${ }^{* *}$ significant at $5 \%$; ${ }^{* * *}$ significant at $1 \%$

Coefficients for Baseline Variables (Table 3, column 4) and Wave

Variables not shown

All columns are Ordered Probit estimations 


\section{Discussion Paper Series}

Mannheim Research Institute for the Economics of Aging Universität Mannheim

To order copies, please direct your request to the author of the title in question.

\begin{tabular}{|c|c|c|c|}
\hline Nr. & Autoren & Titel & Jahr \\
\hline $151-07$ & $\begin{array}{l}\text { Alexander Ludwig, } \\
\text { Thomas Schelkle, } \\
\text { Edgar Vogel }\end{array}$ & $\begin{array}{l}\text { Demographic Change, Human Capital and } \\
\text { Endogenous Growth }\end{array}$ & 07 \\
\hline $152-07$ & $\begin{array}{l}\text { Karsten Hank } \\
\text { Stephanie Stuck }\end{array}$ & $\begin{array}{l}\text { Gesellschaftliche Determinanten produktiven } \\
\text { Alterns in Europa }\end{array}$ & 07 \\
\hline $153-07$ & $\begin{array}{l}\text { Axel Börsch-Supan } \\
\text { Christina B. Wilke }\end{array}$ & $\begin{array}{l}\text { Szenarien zur mittel- und langfristigen } \\
\text { Entwicklung der Anzahl der Erwerbspersonen } \\
\text { und der Erwerbstätigen in Deutschland }\end{array}$ & 07 \\
\hline $154-07$ & $\begin{array}{l}\text { Alexander Ludwig, } \\
\text { Alexander Zimper }\end{array}$ & $\begin{array}{l}\text { A Parsimonious Model of Subjective Life } \\
\text { Expectancy }\end{array}$ & 07 \\
\hline $155-07$ & $\begin{array}{l}\text { Alexander Zimper, } \\
\text { Alexander Ludwig }\end{array}$ & Attitude polarization & 07 \\
\hline $156-08$ & $\begin{array}{l}\text { Florian Heiss, } \\
\text { Daniel McFadden, } \\
\text { Joachim Winter }\end{array}$ & $\begin{array}{l}\text { Mind the Gap! Consumer Perceptions and } \\
\text { Choices of Medicare Part D Prescription Drug } \\
\text { Plans }\end{array}$ & 08 \\
\hline $157-08$ & Wolfgang Kuhle & Demography and Equity Premium & 08 \\
\hline $158-08$ & $\begin{array}{l}\text { Axel Börsch-Supan, } \\
\text { Tabea Bucher-Koenen, } \\
\text { Anette Reil-Held, } \\
\text { Christina Wilke }\end{array}$ & $\begin{array}{l}\text { Zum künftigen Stellenwert der ersten Säule im } \\
\text { Gesamtsystem der Alterssicherung }\end{array}$ & 08 \\
\hline $159-08$ & $\begin{array}{l}\text { Tabea Bucher-Koenen, } \\
\text { Christina Benita Wilke }\end{array}$ & $\begin{array}{l}\text { Zur Anhebung der Altersgrenze: Eine Simulation } \\
\text { der langfristigen Auswirkungen auf die gesetz- } \\
\text { liche Rentenversicherung bei unterschiedlichem } \\
\text { Renteneintrittsverhalten }\end{array}$ & 08 \\
\hline $160-08$ & Mathias Sommer & $\begin{array}{l}\text { Imputation and Harmonisation of Income, } \\
\text { Consumption, Savings and Wealth Data from } \\
\text { the German Income and Expenditure Survey }\end{array}$ & 08 \\
\hline $161-08$ & Karsten Hank & Generationenbeziehungen im alternden Europa & 08 \\
\hline $162-08$ & $\begin{array}{l}\text { Axel Börsch-Supan, } \\
\text { Karsten Hank, } \\
\text { Hendrik Jürges, } \\
\text { Mathis Schröder } \\
\end{array}$ & $\begin{array}{l}\text { Longitudinal Data Collection in Continental } \\
\text { Europe: Experiences from the Survey of Health, } \\
\text { Ageing and Retirement in (SHARE) }\end{array}$ & 08 \\
\hline $163-08$ & Martin Salm & Job loss does not cause ill health & 08 \\
\hline
\end{tabular}

